\title{
The Emotional Expressions of Chinese People in Batam Island
}

\author{
Wilis Srisayekti and Jeany Hesty Buana \\ Faculty of Psychology \\ Padjadjaran University, Bandung
}

\begin{abstract}
Chinese people have long been a subject in the social history in Indonesia and their emotional expressions in front of the public especially have been affected by history. The previous empirical research findings in the Batam Island showed that Chinese people had unique emotional expression and this uniqueness may inflict interpersonal conflict with people of other ethnicities. This research was held to describe the emotional expression of the Chinese in the Batam Island. Their expressions compared with those of non Chinese. The adapted Display Rules Assessment Inventory (Matsumoto \& Yoo, 2007) were distributed to the research participants (men and women in the Batam Island, totally 195 Chinese and 132 non Chinese). The analysis data result were presented in percentage and it showed that there were several similarities and differences between these two ethnic groups on (1) the display rules of seven basic emotions and (2) the display rules of emotion toward targeted persons, both in public and in private places. Based on the socioculutral paradigm, this finding will help solve any interpersonal - related problems faced by the Chinese with people of other ethnicities in the Batam Island.
\end{abstract}

Keywords: emotional expression, DRAI, sociocultural paradigm, Chinese and non-Chinese, Batam island

Sejarah sosial yang dialami etnis Tionghoa di Indonesia memengaruhi ekspresi emosinya terutama pada situasi publik. Temuan empirik terdahulu di pulau Batam memperlihatkan bahwa keunikan ekspresi emosi etnis tersebut dapat memunculkan salah paham dan memicu konflik interpersonal, khususnya dengan etnis lain. Studi ini bermaksud menggambarkan ekspresi emosi warga beretnis Tionghoa di pulau Batam, dibandingkan dengan ekspresi emosi warga beretnis non-Tionghoa. Display Rules Assessment Inventory (Matsumoto \& Yoo, 2007) yang teradaptasi, disampaikan kepada partisipan (laki-laki dan perempuan, 195 orang beretnis Tionghoa dan 132 beretnis non-Tionghoa di pulau Batam). Berbentuk persentase, hasil analisis memaparkan persamaan dan perbedaan dari dua kelompok partisipan tentang (1) the display rules of emotion pada tujuh emosi dasar, dan (2) the display rules of emotion tersebut terhadap person target, di situasi publik dan situasi personal. Dengan penjelasan menggunakan paradigma sosiokultural, informasi tersebut dapat dimanfaatkan untuk menolong warga yang menghadapi masalah terkait relasi interpersonal dengan etnis lain di pulau Batam.

Kata kunci: ekspresi emosi, DRAI, paradigma sosiokultural, Tionghoa dan non-Tionghoa, pulau Batam

The Chinese is one minority group of immigrants in Indonesia. According to Turner and Allen (2007), about three percentage of Indonesians now are of Chinese.On the other hand, Sindhunata (2006) said that they make up about three to five percentage of the Indonesians. It is long known in the history of

Correspondence concerning this article should be addressed to Wilis Srisayekti, Faculty of Psychology, Padjadjaran University, Jalan Raya Bandung Sumedang KM 21, Jatinangor 45363 Bandung.

E-mail: wilis_bandung@yahoo.com
Chinese people in Indonesia that they are treated differently compared to people of other ethnicities. This unfortunate condition has long provided them with different social position in the social environment in Indonesia. This difference is felt by not only the Chinese but also people of other ethnicities in Indonesia. This difference inevitably affected the Chinese' behavior in Indonesia (Setiady, 2010).

Racism and discrimination issues have long been related to the Chinese in Indonesia (Setiady, 2010; 
Wibowo, as cited in Mio, Hackett \& Tumambing, 2009). Tracing back to the beginning of their existence in Indonesia, the issues were developed from the society's situation during the colonialism government of the Nederlands Indie, about four centuries ago. The government granted special status to the Chinese as the Foreign Easterners. Consequently, the Chinese social status in the society was higher than the natives. This discriminatory situation was later identified as the beginning of others' prejudice toward the Chinese (Setiady, 2010). Another priviledge given by the Nederlands Indie government to the Chinese was about the land ownership in which the Chinese had the right to own a piece of land. Therefore, they could be landowners while the native was only allowed to rent the land. This right differentiation was thought contributed more or less to the prejudice, racism and discrimination toward the Chinese (Setiady, 2010).

The New Orde regime inevitably intensified the issues and enforced several stipulations. One of the stipulations was the Letter of Citizenship of the Republic of Indonesia. This letter put the Chinese in a different position compared to others in Indonesia. Another stipulation was about the name changing which forced all Chinese people to convert his or her Chinese name into Indonesian sounding name. Moreover, there was Presidential Instruction which banned any social activites related to China, such as Chinese New Year and any event to celebrate Chinese religions. Those three goverment stipulations during the New Orde regime were felt as a restriction and had a great effect to the Chinese in Indonesia (Setiady, 2010).

Years of restrictions imposed to the Chinese eventually made them feel different from people of other ethnicities in Indonesia. They felt uneasy to express their emotions. They also tended to be exclusive and were reluctant to express emotions, especially when they were in public. The Chinese then were notorious of their arrogance and lack of warmth when it comes to social interactions (Buana, 2012). Although many of discriminatory stipulations or laws by the New Orde regime for the Chinese were eventually wiped out during the Reformation era, there were still no data found about whether Chinese people changed their disposition towards expressing emotions (Setiady, 2010).

The Batam Island is included in the Riau Province. Its population was 440.000 inhabitants and most are immigrants and Chinese. The first Chinese generation came to the Batam Island in the 18th century. Most of them worked as fishermen, some converted forests into rubber plantations, some were tradesmen, and skippers. The island is pretty close to Singapore and accordingly, the Batam Island changed into a strategic location for trading and fishery. Nowadays, the Batam Island has developed into an industrial region (Sutrisno, 2006).

Buana (2011) reported that there was no recent data about the number of the Chinese in the Batam Island. Due to unknown reasons the local government of Batam did not publicize the composition of ethnicities in their demographic data. Contrary to other regions in Indonesia, the Batam inhabitants did not oblige to fill the 'ethnicity' columns in any residential administrative affairs. The Chinese in the Batam Island tend to hide their ethnic identity.

According to the society in general, the Chinese in the Batam Island rarely participated in the community activities. Most of the Chinese in the island followed their culture which encouraged them to work hard for their families. As an exchange for their absence in the community activities, the Chinese donated some goods. Unfortunately, their donations was wrongly perceived by some people and they thought that the Chinese were unwilling to socialize. Meanwhile the Chinese said that they were afraid of not being included and acknowledged by the people living around them. This apprehension discouraged them to initiate social interaction, and made them feel uncomfortable in social life. Consequently, the Chinese in the island limited their socialization only with the Chinese (Buana, 2011).

The Chinese in the Batam Island rarely expressed their feeling, especially when they were in public places. They were used to hide their emotions. When this emotion becomes too stressful, then their emotional reactions were unbearably manifested (Buana, 2011). Further, Buana said that the Chinese in the island often avoided negative emotion expression such as anger. They inclined to switch the negative emotions and pretended that nothing happened. The people in the Batam Island in general thought that the Chinese lack emotional sensitivity, therefore they did not fully understand what happened to them nor truly involved in social relations. Consequently when it comes about social interactions with others, the Chinese appeared to be less expressive, but when they were close enough with their peers, they would be more expressive. This situation was significantly dissimilar with the traits of the native people in the Batam Island. The native might suffer from misunderstanding that eventually led to interpersonal conflicts (Buana, 2011). 
In fact, the differences of emotional expressions between the Chinese and the non-Chinese often put the Chinese in difficulty to intensely socialize with the non-Chinese, such as the Malayan, the Javanese, the Minangs and the Bataks and others. It was quite common in the Batam Island, that the Chinese were less sociable and less friendly when they encounter others. The lack of understanding about the reasons behind the Chinese social behavior and facial expression might create further misunderstanding. The phenomenon of this misunderstanding was observed when a Chinese teenager mingled with his or her peers. Also when a non-Chinese teacher in a class responded to the behavior of his or her Chinese pupils (Buana, 2012). This study was held to get better understanding about the emotional expressions of the Chinese in the Batam Island. By doing so, the problem of social interaction due to the misunderstanding and wrong perception about the Chinese emotional expressions would be less likely to happen. It was also expected that teachers, especially non-Chinese teachers in the island, could deliver appropriate response to the Chinese students. Further, the teachers could provide better support for the students.

The phenomenon of emotional expressions in this study was regarded through sociocultural point of view proposed by Holodynski, Friedlmeier and Harrow (2006). They considered emotion as an individual's regulation function to perceive a stimuli, which was related to the motive and individual's interaction with his or her social environment. There were aspects of emotion such as (1) feeling, that was a sense resulted from an individual's perceive toward a stimuli, and this is not a behavior, (2) physiological reaction, that is a physiological change as a sequence of feeling, (3) expressions, that was expressive movement shown by the individual to disclose his or her feeling. Integrated in emotion were social and cultural context. Emotion and its regulations were inseparable from the interpersonal interaction. This concept was developed based on the premise that not all human abilities existed in the early stage of human evolution, but some were constituted later by humans themselves.

One of the human beings' self-developed abilities was the ability to develop cultures, to manipulate nature in order to made it suitable and filled human beings' needs (rearrange), through the creation of artifacts such as tools and signs. These abilities passed on from one generation to the next as cultural inheritance. The human cultures went through a pro- cess of evolution and the cultures were no longer genetically acquired but learned (learning) (Cole, 1996; Leontiev, 1981; Valsiner, 2003; Vygotsky 1931/1997, Lorenz, 1977; in Holodynski et al., 2006). It is also important to note that a second external 'memory store' played an important role in this learning process.

Matsumoto (2000, as cited in Holodynski et al., 2006) argued that memory store's content was not only about technical and procedural matters to deal with the natural world, but also social artifacts and the procedures for humans' interactions with its norm and values system. The cultural meaning systems contains experiences related to certain strong emotions and its effects, its functions and coping actions, and rules on context - specific appropriateness of emotion. The rules covered not only interpersonal relationship but also intrapersonal action regulations. The cultural meaning systems was a sort of reconstruction of experienced emotional practice, and this systems was used as a base for an individual to reflect on his or her emotions. The cultural meaning systems also contained of identification process of causes, effects and the consequences of emotions. The systems were then internalized by the individual and became part of the personality through which the individual was able to manage her/his emotions. In the human development, the complete understanding of culture systems would be constituted during childhood as the child grow in the family as the closest adults to the child.

Holodynski et al. (2006) further proposed that cultural dimensions created new things in the development of human emotions. This is in line with Ekman's argument (1992) that emotion was universal. This perspective showed that cultural context was not only a place for the adaptive emotional expression and function which came naturally, more than that, Holodynski et al (2006) argued that cultural context provided emotional scripts and patterns of meaning. This is important for the development of emotional expressions and regulations. And for years, through one generation to the next, people inherited and accumulated this expression and regulations of emotions. In other words, individual differences in the expressions, functions and regulations of emotions were likely found to be qualitatively new within a cultural context. Emotional regulations were then integrated by any child to his/her self understanding systems (Holodynski et al., 2006).

Based on what was stated by Holodynski et al. (2006) it was concluded that emotion was part of 
Table 1

The Participants of the Study

\begin{tabular}{lcccrr}
\hline Ethnic & \multicolumn{3}{c}{ Sum (Participants) } & Age (Years) \\
\hline & Male & Female & Total & $M$ & $S D$ \\
Chinese & 99 & 96 & 195 & 16.71 & .673 \\
Non-Chinese & 73 & 59 & 132 & 16.57 & .679 \\
\hline
\end{tabular}

personal matters covering intrapsychic and cultural origin. The emotional expression, function and regulation were not naturally acquired and developed through a process of maturation, it was obtained through the culture learned and internalized into one's personality and intrapsychic. Individual's emotional development mechanism was considered as one's ability to transform specific emotional expression that was culturally-related into something personal for the purpose of personality development during the adolescent phase of development, and this mechanism remain relatively stable during adult life.

Based on what Holodynski et al. (2006) argued about emotions, the Chinese in the Batam Island likely learned emotions and emotion-related matters differently from people of other ethnicities. Consequently, the Chinese perceive all emotional affairs in a way that is incompatible with others in the island. From the three perspectives of emotion proposed by Holodynski et al., this study was focused on emotional expression as the continuation of the empirical findings described by Buana (2011, 2012). This research aimed to describe emotional expression of the Chinese in the Batam Island and compare them with the emotional expression of the non-Chinese in the island.

\section{Method}

\section{Participants}

Table 1 shows the description of the research participants. One hundred and ninety five Chinese (99 men and 96 women) in the Batam Island participated in this study. The age average was 16.71 years old $(\mathrm{SD}=.673)$. And 132 non-Chinese participants (73 men and 59 women) with the age average 16.57 years $(\mathrm{SD}=.679)$ also participated.

Chinese participants in this study were those with Chinese parents. The subjects were born and raised in the Batam Island. It was assumed that the participants followed the Chinese norms and values in their daily lives. Their mother language were Teochew (46.7\%), Mandarin (20\%), the Bahasa Indonesia
(18\%), Hokkian 11.3\%), Khek (2.5\%), and Kanton (1.5\%). In this study, Chinese referred people with Chinese ethnicity.

The non-Chinese subjects in this study were people with non-Chinese parents, born and grown up in the Batam Island. The subjects included 17 ethnicities in Indonesia, such as Batak, Riau Malayan, Manado, Sunda, Padang, Betawi, Palembang, Flores, Bali, Nias, Makassar, Dumai, Bugis, Banten, Sangier, Toraja. Their mother language were Bahasa Indonesia (89.4\%), Malayan (7.8\%), Java (2\%) and Padang (0.8\%). In this study, non-Chinese were people with non-Chinese ethnicities.

Considering that the Batam Island local government did not publish any ethnicities data in the formal demographic information (Buana, 2011), the participants in this study were chosen among school adolescents. This was because details of their ethnicities were recorded in the students' data. All participants were adolescents students of the High School in the Batam Island (Chinese participants $M=16.71 S D=$ .673; non-Chinese participants $M=16.57 S D=.679$ ). Based on the argument proposed by Holodynski et al. (2006), it was assumed that transformational process of specific emotional expressions which were cultural, would become personal. The developing specific emotional expression had manifested during the adolescent phase of development, and the expression would be stronger and more stable in their adult life.

\section{Measures}

Self-report questionnaire the Display Rules Assessment Inventory (DRAI) was developed by Matsumoto and Yoo (2007) and was then adapted into the Bahasa Indonesia by Djunaidi, Setiono, and Purwono. (2008). The questionnaire was contructed based on the display rules of emotion by Ekman and Friesen (1969). This questionnaire was mainly used to assess emotional expression influenced by cultural context, either in public or private places. For the purpose of this study, the emotional expression was defined as cultural rules or the culture of universal emotional expression in social situations. 
Table 2

The Universal Basic Emotions as Written in the Manual of DRAI by Matsumoto

\begin{tabular}{|c|c|c|}
\hline Universal Basic Emotion & & Definition \\
\hline Happiness & : & having a feeling of great pleasure, contentment, joy \\
\hline Anger & : & $\begin{array}{l}\text { a feeling of displeasure resulting of injury, mistreatment, opposition, and } \\
\text { usually showing itself in a desire to fight back at the supposed cause of feeling }\end{array}$ \\
\hline Disgust & : & a sickening distaste or dislike \\
\hline Fear & : & $\begin{array}{l}\text { a feeling of anxiety and agitation caused by th presence or nearness of danger, } \\
\text { evil, or pain }\end{array}$ \\
\hline Sadness & : & having low spirits or sorrow \\
\hline Surprise & : & to come upon suddenly, or unexpectedly \\
\hline Contempt & : & $\begin{array}{l}\text { a feeling or attitude of one who looks down on somebody or something as being } \\
\text { low, mean, or unworthy }\end{array}$ \\
\hline
\end{tabular}

Note. Manual p. 2; see also Matsumoto, Yoo, Hirayama, \& Petrova, 2005

Table 3

The Display Rules of Emotion as Written in the Manual of DRAI by Matsumoto

\begin{tabular}{ll}
\hline Display Rules of Emotion & Definition \\
\hline Amplification & $:$ Show more than the participants feel it \\
Qualification & $:$ Express it as the participants feel it \\
& $:$ Show what the participants feel it, but with another expression \\
Deamplification & $:$ In this study: Show what the participants feel it but at the same time smiling \\
Masking & $:$ Hide the participations feeling by showing something else \\
& $:$ In this study: the participants hide the feeling with smiling \\
Neutralization & Hide the participants feeling by showing nothing \\
\hline
\end{tabular}

Note. Manual, p. 1; see also Matsumoto, Yoo, Hirayama, \& Petrova, 2005

Using the questionnaire, participants were technically asked to think of a target person in their life in every given situation. They were then asked to share what they thought they should have done. In doing this, they could choose one of the seven options provided. Table 2 and Table 3 described several concepts of the universal basic emotions and the display rules of emotion according to Ekman dan Friesen (1969), as written in the manual of DRAI by Matsumoto (n.d.).

The DRAI also consisted of items on participants' relationship with the ones they think of, when they answered the previous questions. This questionnaire was not included in this study.

In the original questionnaire there were 21 target persons, classified into five groups: family (mother, father, older sister and older brother, younger sister and younger brother), close friends (male and female), acquaintances (male and female), schoolmates (higher, lower, classmates, both male and female), other students (male and female), teachers/professors (between 50-60 years and between 30-40 years, male and female). And this study used all the five categories, they were: family (mother, father, older sister and older brother, younger sister and younger brother), close-friends (male and female close-friends), acquaint- ances (male and female acquaintances), schoolmates (senior and junior schoolmates, male and female schoolmates and classmates), teachers (male and female teachers).

\section{Scoring}

All the participants' responses were coded according to the display rules of emotion such as Neutralization (coded 1), Masking (coded 2), Deamplification (coded 3), Qualification (coded 4), Expression (coded 5), Amplification (coded 6). The responses for the display rules of emotion and for the five categories of the target persons were counted as percentage.

\section{Results}

The research findings showed several descriptions of the display rules of emotion and the target persons.

\section{Description of the Display Rules of Emotion}

The following figures showed the display rules of emotion of all the research participants when they 


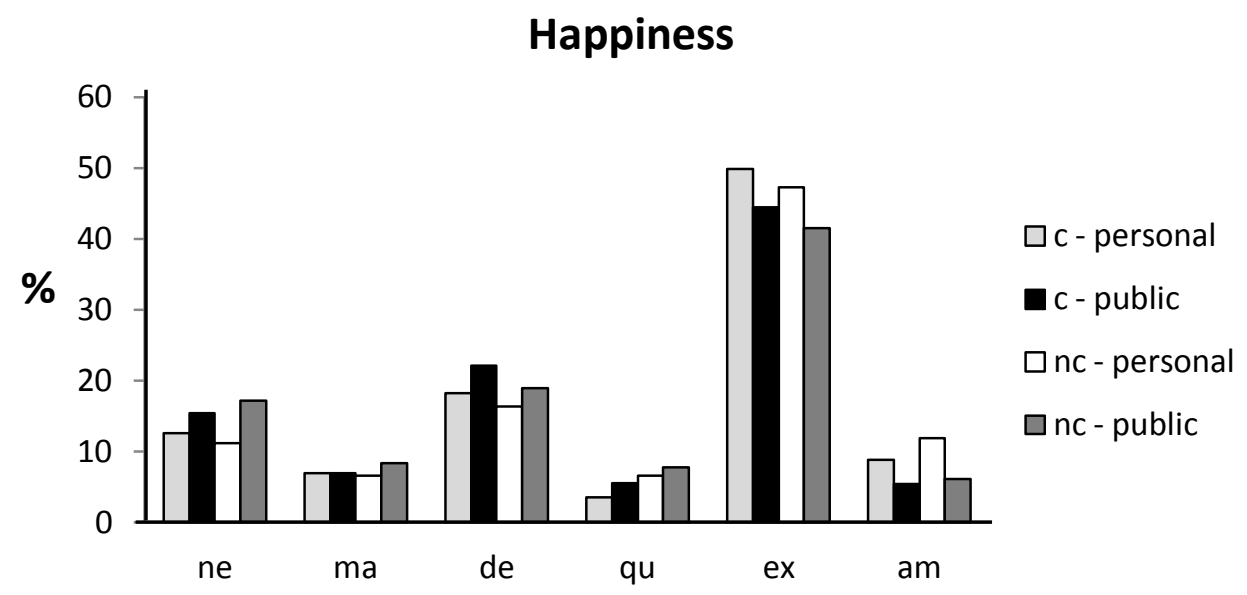

Figure 1. The display rules of 'happiness' in personal and public situations for Chinese (c) and non-Chinese (nc) participants.

$\mathrm{Ne}=$ Neutralization $; \mathrm{de}=$ Deamplification $; \mathrm{ex}=$ Expression; $\mathrm{ma}=$ Masking $; \mathrm{qu}=$ Qualification $; \mathrm{am}=$ Amplification

expressed the seven basic emotions offered by Ekman dan Friesen (1969) as it was written in the DRAI manual. The seven basic emotions were happiness, anger, sadness, fear, surprise, disgust and contempts. The figures were then followed by a summary of the similarity and differences of choices of the two research participants groups when they expressed the basic emotions.

Figure 1 showed that all the six rules of the display rules of emotion proposed by Ekman and Friesen (1969) were chosen by both the Chinese and nonChinese, to show happiness either in public or in private places.

Most of the Chinese were more likely to chose 'expression' to show happiness than other display rules of emotion (in private place $=49.8 \%$; in public place $=44.5 \%$ ). The next option chosen was deamplification (in private place $=18.2 \%$; in public place $=22.1 \%$ ) and neutralization (in private place $=12.6 \%$; in public place $=15.4 \%$ ). The three other options chosen by less than $10 \%$ of the Chinese participants were masking (in private place $=7 \%$; in public place $=7 \%$ ), qualification (in private place $=$ $3.6 \%$; in public place $=5.6 \%$ ), and amplification (in private place $=8.8 \%$; in public place $=5.4 \%$ ). The Chinese as a whole chose siginificantly different display rules of emotion to express happiness in private and in public places $(z=-6.581 ; p=.000)$.

The non Chinese generally chose 'expression' to show happiness than other display rules of emotion (in private place $=47.3 \%$; in public place $=41.5 \%$ ). The next two options chosen were the same as the
Chinese, deamplification (in private place $=16.4 \%$; in public place $=18.9 \%$ ) and neutralization (in private place $=11.2 \%$; in public place $=17.2 \%$ ) The non Chinese then chose three other options that were amplification (in private place $=11.9 \%$; in public place $=6.2 \%$ ), masking (in private place $=$ $6.6 \%$; in public place $=8.4 \%$ ) and qualification (in private place $=6.6 \%$; in public place $=7.8 \%$ ). The non-Chinese as a whole chose siginificantly different display rules of emotion to express happiness in private place and in public place $(z=-6.685 ; p=.000)$.

Generally the Chinese and the non-Chinese in Batam chose the same option to express happiness in both public and private place. They were likely to chose 'expression' and 'amplification' for expressing happiness in private place than in public place. The other four options; neutralization, masking, deamplifications and qualifications, were treated differrently. The research participant tend to choose the four options to express happiness more when they were in public place than in private place. These different options chosen for expressing happiness in both private and public place, for all participants, was found to be entirely significant.

Figure 2 described that the six diplay rules of emotion proposed by Ekman and Friesen (1969) were chosen by both the Chinese and the nonChinese participants to express anger, either in private or in public place.

Most of the the Chinese prefered neutralization to express anger to other rules (private $=27.5 \%$; public $=40.6 \%)$. They also tended to choose 'expression' 


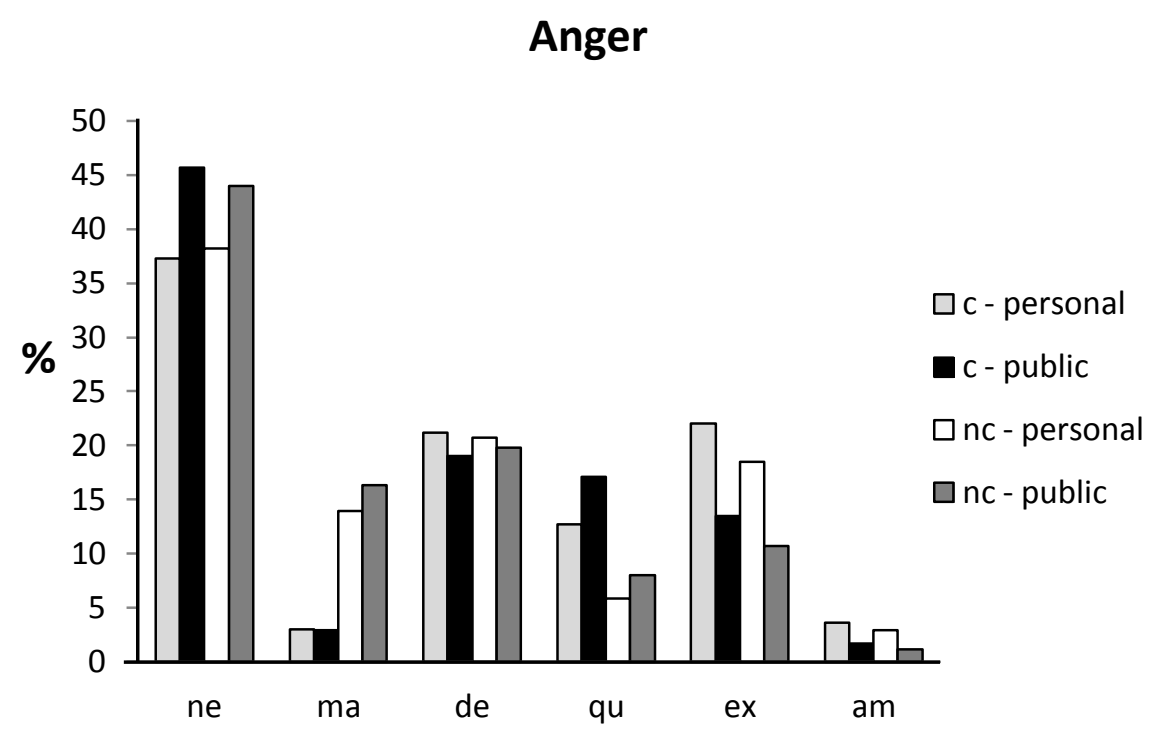

Figure 2. The display rules of 'anger' in personal and public situations for Chinese (c) and non-Chinese (nc) participants.

$\mathrm{Ne}=$ Neutralization $; \mathrm{de}=$ Deamplification $; \mathrm{ex}=$ Expression; $\mathrm{ma}=$ Masking $; \mathrm{qu}=$ Qualification $; \mathrm{am}=$ Amplification

(private $=22.7 \% ;$ public $=9.7 \%)$ and deamplification (personal $=19.1 \%$; public $=18.1 \%)$. The Chinese participants also slightly prefered the other three rules to express anger, such as qualification (private $=16 \%$; public $=18.8 \%$ ), masking $($ private $=9.1 \%$; public $=9.4 \%$ ), and amplification (private $=5.6 \%$; public $=3.4 \%$ ). The Chinese generally chose significantly different options of diplay rules of emotion to express anger in private and in public place $(z=-10.467 ; p=.000)$.

The non-Chinese participants prefered neutralization to other display rules of emotion, to express anger (private $=24.9 \%$; public $=31.7 \%$ ). The second biggest preference of display rules, to express anger, were 'expression.'(private $=24.7 \%$; public $=13.5 \%)$ and masking $($ private $=11.2 \%$; public $=17.2 \%)$. Then they chose deamplification ( private $=13.3 \%$; public $=13.4 \%$ ), qualification (private $=11.2 \%$; public $=13.1 \%$ ), and amplification (private $=4.8 \%$; public $=2.2 \%$ ). The non-Chinese entirely and significantly chose different display rules of emotion to express anger in private and in public places $(z=-7.171 ; p=.000)$.

Related to private and public places, Figure 2 showed that generally all participants had the same display rules to express anger. They were more likely chose neutralization, qualification and masking to express anger in public places. But deamplification, expression and amplification were for expressing anger in private places. There was a significant difference between the Chinese and the non-Chinese in choosing display rules of emotion in both private and public places. When it comes to expressing anger, there were more non Chinese participants who chose masking as the display rule of emotion than the Chinese. But there were more Chinese participants who took qualification than the non-Chinese.

Figure 3 showed that the six rules of emotion display proposed by Ekman and Friesen (1969) were chosen by both the Chinese and non-Chinese to express sadness, either in private or in public place.

The Chinese participants mostly chose neutralization more than other display rules of emotion to express sadness, and this option was taken more in public place $(45.7 \%)$ than in private place $(37.3 \%)$. For private place, the Chinese chose expression $(22 \%)$ and deamplification $(21.2 \%)$ to express sadness, and there were a few who took deamplification (19\%) and qualification $(17.1 \%)$ as the display rules of emotion to express sadness in public places. There were three other option also taken by the Chinese in expressing sadness, in lesser percentages. They chose qualification to express sadness in private place (12.7\%), and amplification (3.6\%) and masking (3\%). For public place, they chose expression (13.5\%), masking (2.9\%) and amplification $(1.7 \%)$. In general, the Chinese participants express- 


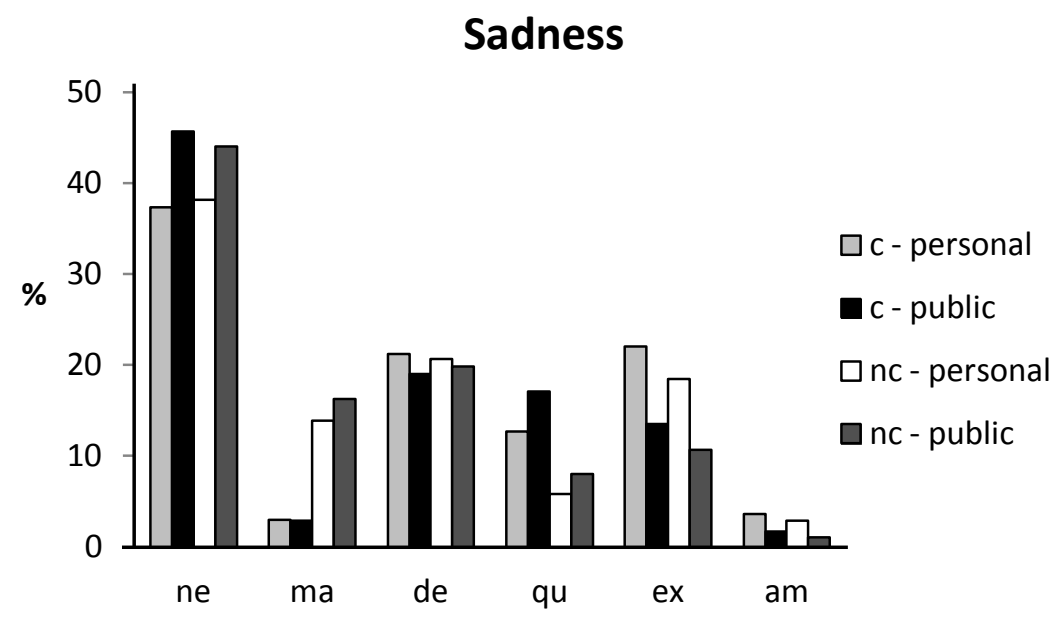

Figure 3. The display rules of 'sadness' in personal and public situations for Chinese (c) and non-Chinese (nc) participants.

$\mathrm{Ne}=$ Neutralization $; \mathrm{de}=$ Deamplification $; \mathrm{ex}=$ Expression $; \mathrm{ma}=$ Masking $; \mathrm{qu}=$ Qualification $; \mathrm{am}=$ Amplification

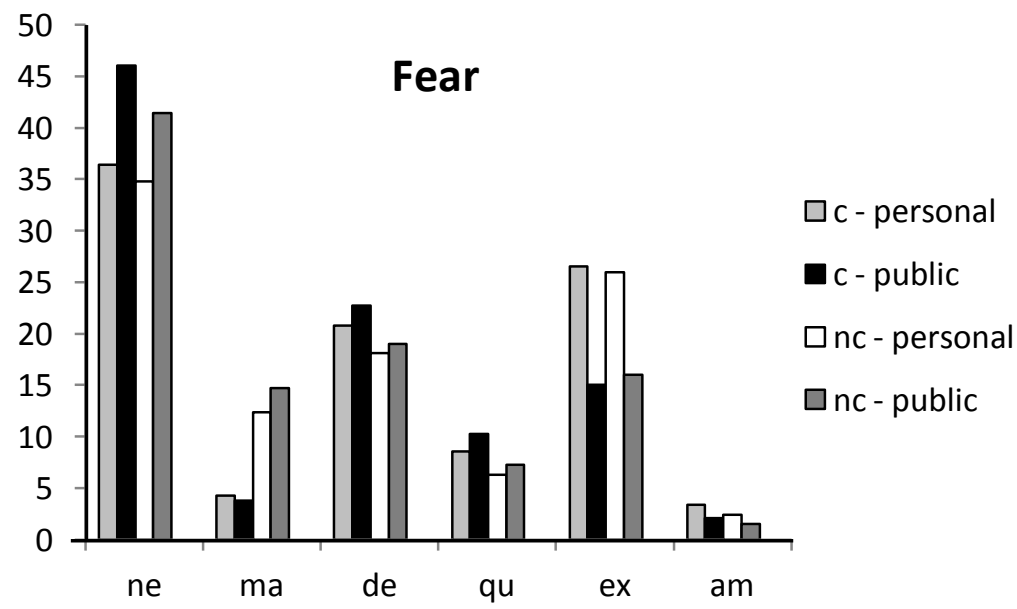

Figure 4. The display rules of 'fear' in personal and public situations for Chinese (c) and non-Chinese (nc) participants.

$\mathrm{Ne}=$ Neutralization $; \mathrm{de}=$ Deamplification $; \mathrm{ex}=$ Expression $; \mathrm{ma}=$ Masking $; \mathrm{qu}=$ Qualification; $\mathrm{am}=$ Amplification

ed sadness significantly different in private and in public places $(z=-7.356 ; p=.000)$.

The non-Chinese participants mostly also chose neutralization to express sadness (in private $=38.2 \%$; in public $=44 \%$ ). They also chose deamplification $(20.7 \%)$ and 'expression' (18.5\%) as the display rules of emotion to convey sadness in private places, and deamplification (19.8\%) and masking (16.3\%) in public places. There were three other options also taken by the non-Chinese in expressing sadness, in lesser percentage. For private places, the non-Chinese chose masking (13.9\%), qualification $(5.8 \%)$ and amplification (2.9\%) and for public places, they chose expression (10.7\%), qualification (8\%) and amplification $(1.1 \%)$. In general, the non-Chinese participants expressed sadness significantly different in private and in public places $(z=-6.037 ; p=.000)$.

Based on the figures, it was concluded that the Chinese and the non-Chinese participants likely had the same choices to express sadness in both private and public places. They all prefered neutralization to show their sadness in public places more than in private places. But the other five alternatives (masking, deamplification, qualification, 'expression', and 


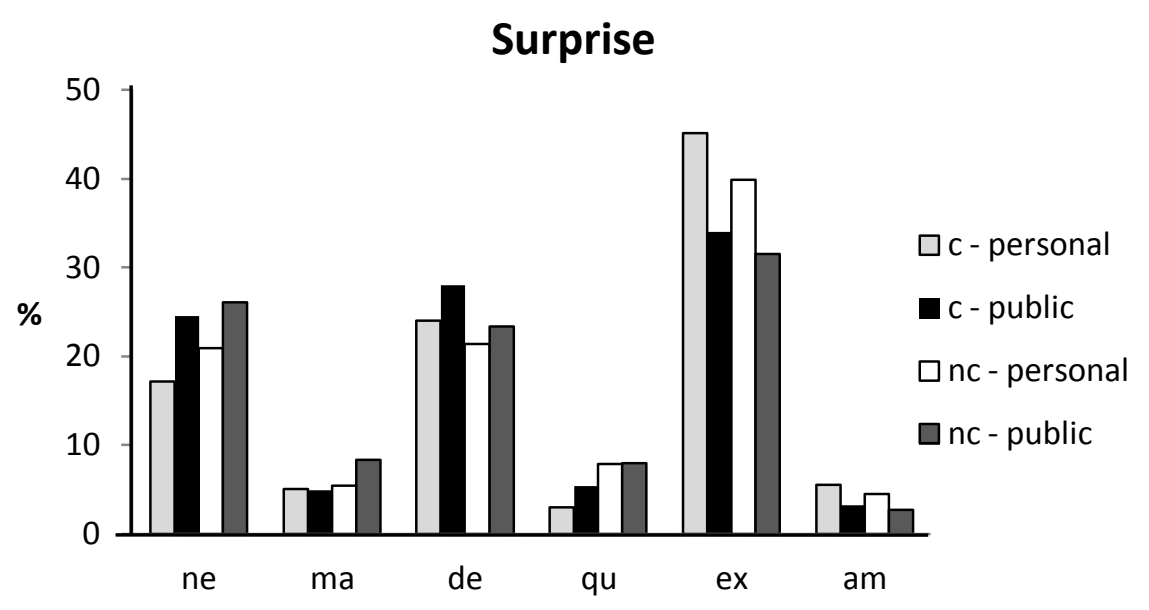

Figure 5. The display rules of 'surprise' in personal and public situations for Chinese (c) and non-Chinese (nc) participants.

$\mathrm{Ne}=$ Neutralization $; \mathrm{de}=$ Deamplification; $\mathrm{ex}=$ Expression; $\mathrm{ma}=$ Masking; qu = Qualification; $\mathrm{am}=$ Amplification

amplification) were chosen to express sadness more in private places. This different preference toward the display rules of emotion to express sadness either in private or in public places for the Chinese and non-Chinese participants were significant.

Figure 4 showed that all the six display rules of emotion proposed by Ekman and Friesen (1969) were chosen by both the Chinese and non-Chinese, to show fear either in public or in private.

The Chinese participants mostly chose neutralization more than other display rules of emotion to express fear. Neutralization was chosen to express fear more in public place (46\%) than in private place (36.4\%). For private place, the Chinese chose expression $(26.5 \%)$, deamplification (20.8\%), qualification $(8.6 \%)$, masking $(4.3 \%)$ and amplification $(3.4 \%)$. For public place, they chose deamplification $(22.7 \%)$, expression (15\%), qualification (10.3\%), masking $(3.8 \%)$ and amplification (2.1\%). In general, the Chinese participants; way of expressing fear in private and public places were significantly different $(z=-8.090 ; p=.000)$.

The non-Chinese participants also mostly chose neutralization more than other display rules of emotion to express fear. Similar to their counterpart, the neutralization was chosen to express fear more in public place $(41.4 \%)$ than in private place $(34.8 \%)$. For private place, the non-Chinese showed their fear through the display rules expression (26\%), deamplification $(18.1 \%)$, masking (12.4\%), qualification $(6.3 \%)$ and deamplification (2.4\%). For public place, they chose deamplification (19\%), expression
(16\%), masking (14.7\%), qualification (7.3\%) and amplification (1.5\%). In general, the non-Chinese showed a significant difference in displaying their fear in private and in public place $(z=-5.678$; $p=.000)$.

The figures presented that the Chinese and the non-Chinese participants had the same display rules of emotion to express fear in both private and public places. They all preferred deamplification, 'expression' and amplification to show their fear in private places more than in public places. And neutralization, masking and qualification were chosen to show fear in public places. This different preference toward the display rules of emotion to convey fear either in private or in public places for the Chinese and non-Chinese participants was generally significant.

Figure 5 showed that all the six display rules of emotion proposed by Ekman and Friesen (1969) were chosen by both the Chinese and non-Chinese, to show surpise either in public or in private.

The Chinese participants mostly chose 'expression' to show surprise. This 'expression' was more frequently chosen for private place $(45.1 \%)$ than for public place $(34 \%)$. They also chose deamplification (private $=24 \% ;$ public $=28 \%)$ and neutralization (private $=17.2 \%$; public $=24.5 \%$ ). In lesser percentage, the Chinese also disclosed surprise through the other display rules. For private places, they prefered amplification $(5.5 \%)$, masking $(5.1 \%)$ and qualification $(3 \%)$; and for private places they chose qualification (5.4\%), masking (4.9\%) and amplification (3.2\%). The Chinese generally chose significantly 


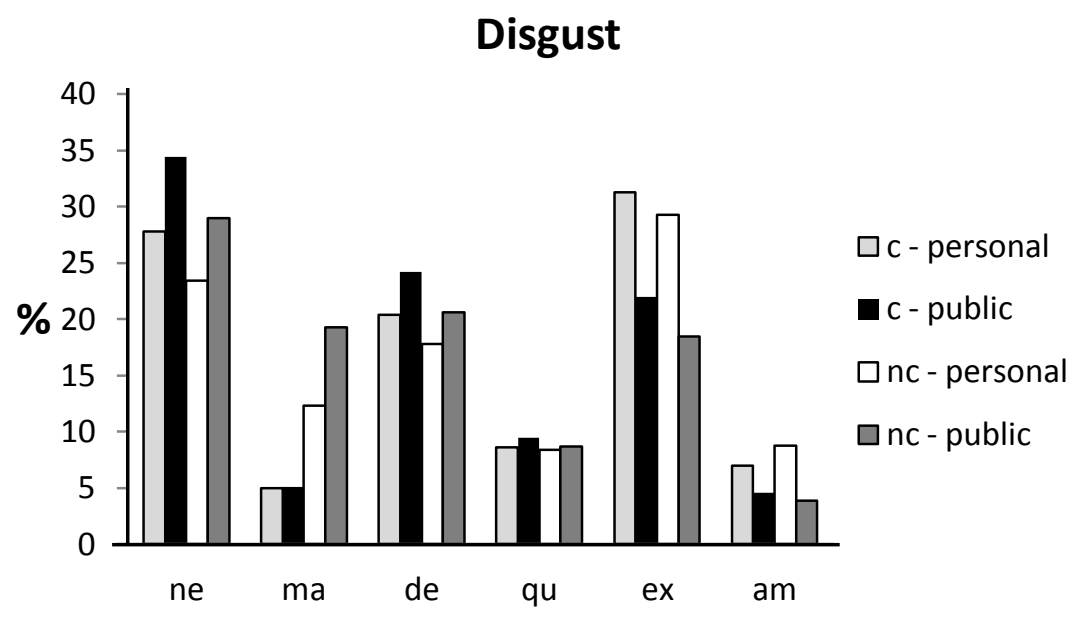

Figure 6. The display rules of 'disgust' in personal and public situations for Chinese (c) and non-Chinese (nc) participants.

$\mathrm{Ne}=$ Neutralization $; \mathrm{de}=$ Deamplification $; \mathrm{ex}=$ Expression $; \mathrm{ma}=$ Masking; $q \mathrm{qu}=$ Qualification; $\mathrm{am}=$ Amplification

different display rules to show surprise in private and in public places $(z=-7.916 ; p=.000)$.

The non-Chinese participants mostly chose 'expression' to show surprise in private place $(45.1 \%)$ than in public place $(34 \%)$. They also chose deamplification (private $=24 \%$; public $=28 \%$ ) and neutralization (private $=17.2 \%$; public $=24.5 \%$ ). In lesser percentage, the Chinese also showed surprise through the other display rules. For private places, they preferred amplification (5.5\%), masking (5.1\%) and qualification (3\%); and for private places they chose qualification (5.4\%), masking (4.9\%) and amplification (3.2\%). The non-Chinese generally chose significantly different display rules to show surprise in private and in public places $(z=-7.916 ; p=.000)$.

The figure showed that the Chinese and the nonChinese participants likely had the same display rules to express surprise in both private and public places. They all prefered 'expression' and amplification display rule to show surprise in private places more than in public places. Neutralization and deamplification were chosen to convey suprise more in public places than in private ones. The Chinese and the non-Chinese had different choices to show surprise in private and in public places, that were masking and qualification.

Figure 6 showed that all the six display rules of emotion proposed by Ekman and Friesen (1969) were chosen by both the Chinese and non-Chinese, to show disgust either in public or in private places.

The Chinese participants had three first choices to show disgust in private places and the choices in sequence were 'expression' (31.3\%), neutralization (27.8\%), deamplification (20.4\%); but in public places, their first three choices were neutralization (34.4\%), deamplification (24.2\%) and 'expression' (22\%). The next three choices to show disgust in private places were qualification $(8.6 \%)$, amplification (7\%), masking (5\%), and the following three choices for public places were qualification (9.5\%), masking $(5.1 \%)$, and amplification (4.6\%). The Chinese generally chose significantly different display rules to show disgust in private and in public places $(z=-7.916 ; p=.000)$.

The non-Chinese participants seemed to be similar with the Chinese in showing disgust. The first three choices taken by the non-Chinese to express disgust in private places were 'expression' (29.3\%), neutralization $(23.4 \%)$ and deamplification $(17.8 \%)$; and their first three choices to show disgust in private places were neutralization (29\%), deamplification (20.6\%) and masking (19.3\%). The next three choices taken by the non-Chinese to express disgust in private places were masking $(12.3 \%)$, amplification $(8.8 \%)$, qualification $(8.4 \%)$. But in public places, the non-Chinese express their disgust through 'expression' $(18.5 \%)$, qualification $(8.7 \%)$, amplification (3.9\%). The non-Chinese expressed disgust in significantly different ways in private and public places $(z=-7.117 ; p=.000)$.

The figure presented that generally the Chinese and the non-Chinese participants likely had the same display rules to express disgust more in private places than in public places. They all preferred the 


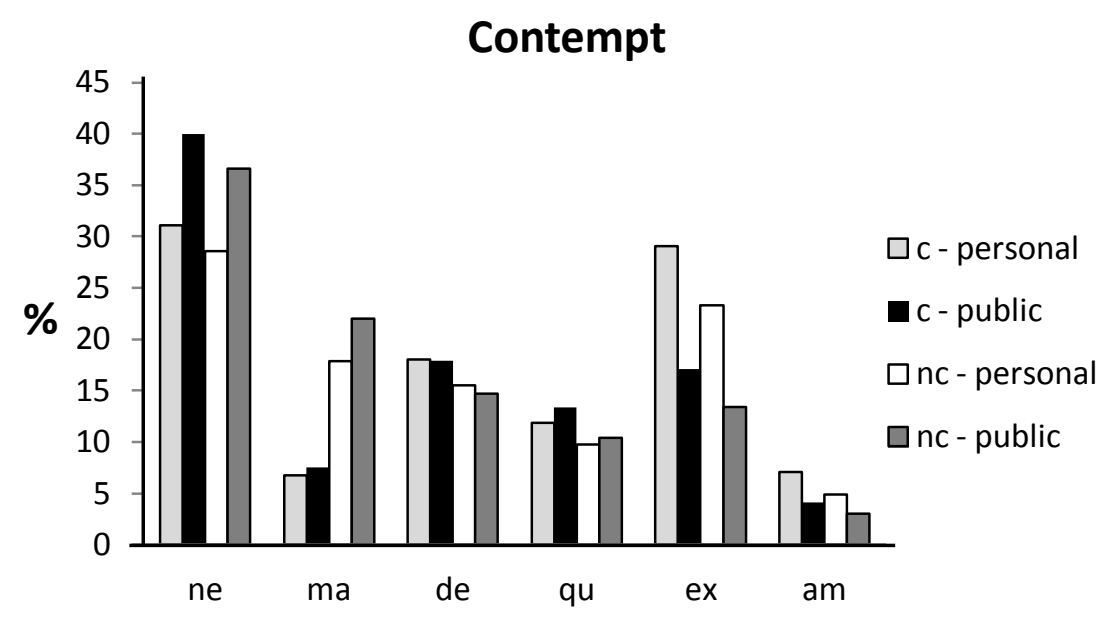

Figure 7. The display rules of 'contempt' in personal and public situations for Chinese (c) and non-Chinese (nc) participants.

$\mathrm{Ne}=$ Neutralization $; \mathrm{de}=$ Deamplification $; \mathrm{ex}=$ Expression; $\mathrm{ma}=$ Masking $; \mathrm{qu}=$ Qualification $; \mathrm{am}=$ Amplification

display rule 'expression' and amplification to show disgust in private places more than in public places. And neutralization and deamplification were chosen to disclose disgust more in public places than in private ones. The Chinese and the non-Chinese had different choices to show disgust in private and in public places. The choices were masking and qualification.

Figure 7 showed that all the six display rules of emotion proposed by Ekman and Friesen (1969) were chosen by both the Chinese and non-Chinese, to show contempt either in public or in private places.

The Chinese participants choose neutralization to show contempt both in private places $(31.1 \%)$ and in public places (40\%). And the choices they took to show contempt in private places in order of percentages were 'expression' (29.1\%), deamplification (18\%); qualification (11.9\%), amplification (7.1\%) and masking $(6.8 \%)$. The next three choices to disclose contempt in public places were deamplification $(17.9 \%)$, 'expression' $(17.1 \%)$, qualification $(13.4 \%)$, (masking $(7.5 \%)$, and amplification $(4.1 \%)$. The Chinese generally chose significantly different display rules to show contempt in private and in public places $(z=-8.399 ; p=.000)$

The non-Chinese participants seemed to show similar choices with the Chinese in showing contempt. They chose neutralization for showing contempt in both private places $(28.6 \%)$ and public ones $(36.6 \%)$. The next three choices taken by the non-Chinese to express contempt in private places were 'expression' $(23.3 \%)$, masking (17.9\%), deamplification $(15.5 \%)$; the three choices taken by the non-Chinese to express contempt in public places were masking (22\%), deamplification (14.7\%), and 'expression' (13.4\%). Although in lesser percentage, the nonChinese also chose qualification (private $=9.8 \%$; public $10.4 \%$ ) and amplication (private $=4.9 \%$; public 3\%). In general, the non-Chinese expressed contempt in significantly different ways between private and public places $(z=-6.502 ; p=.000)$.

Figure 7 showed that in general both groups of participants showed similar tendencies in expressing contempt in private and in public places. They all prefered the display rule 'expression', amplification and deamplification to show contempt in private places more than in public places. And neutralization, masking and qualification were chosen to express contempt more in public places than in private ones.

\section{Results Summary of the Display Rules of Emotion}

The results of display rules chosen by the research participants to convey emotion were summarized in the following section. The summary contained similarities and differences of choices among the participants, in expressing the seven basic emotions in both private and public places.

\section{Similarities}

1. In general, the Chinese and the non-Chinese were not significantly different in choosing the dis- 
play rules of emotion proposed by Ekman and Friesen (1969). They chose all the six display rules to express the seven basic emotions: happiness, anger, sadness, fear, surprise, disgust and contempts. For each display rules chosen, they showed different percentages.

2 . Both the Chinese and the non-Chinese participants chose 'expression', neutralization and amplification to express emotion. The display rule 'expression' and amplification were chosen by the participants to express the seven basic emotion, more in private places than in public ones. They chose the display rule neutralization to express the basic emotion more in public places.

Most of the research participants prefered the display rule 'expression' to show happiness and surprise, and neutralization to express anger, sadness, fear and contempts. The participants chose masking more when they were in public place than in private ones. This display rule was mostly chosen to express happiness, anger, sadness, fear and contempts. The Chinese and the non-Chinese in this research were likely to be different when choosing masking to express surprise and disgust.

The Chinese and the non-Chinese participants differ in their choice of display rules deamplification and qualification to express emotion. Deamplification were more likely chosen by both groups of participants when they were in public places. And this display rule were more to express happiness, surprise and disgust. But deamplification was likely to be taken as an alternate to express anger, sadness and contempts in private places.

The display rule qualification was picked by both groups when they were in public places. This display rule was to express happiness, anger, sadness, surprise and disgust. The percentage of participants who took qualification to express fear differed between the Chinese and the non-Chinese.

\section{Differences}

The difference between the two groups of research participants was shown on their decision to choose masking to express surprise and disgust. The Chinese chose masking to express surprise when they were in private places. On the other hand, the non-Chinese chose masking more to express surprise when they were in public places than in private ones. The display rule masking was picked by the Chinese to express disgust in private places as well as in public places. And there were more non-Chinese participants who picked masking to express disgust in public places than those who chose it in private places.

The differences between the groups were shown when they chose deamplification to express fear. The Chinese expressed fear by using the display rule deamplification more in private places than in public ones. The number of non-Chinese participants who took deamplification to express fear in both private and public places was relatively the same.

The groups showed differences in choosing qualification as the display rule to express fear. The Chinese expressed fear through the display rule qualification more when they were in public places than in private places. The non-Chinese expressed fear with the same display rule either in private or in public places.

\section{The Target Persons}

Table 4 to 6 will describe the display rules of emotion used by the two groups when they faced the target persons and when they expressed the seven basic emotion proposed by Ekman and Friesen (1969) as written in the DRAI manual, both in private and public places. The target persons were family, acquaintances, close friends, school mates and teachers. The descriptions are completed with

Table 4

The Display Rules of Emotion for the Target Persons 'Family' for the Chinese and non-Chinese Participants in Personal and Public Situations

\begin{tabular}{lllr}
\hline \multirow{4}{*}{ Emotion } & & \multicolumn{2}{c}{ Target Persons } \\
\cline { 3 - 4 } & & \multicolumn{2}{c}{$\begin{array}{c}\text { The Highest Display Rules } \\
\text { (\%) }\end{array}$} \\
\cline { 3 - 4 } & & \multicolumn{2}{c}{ Family } \\
Happiness & Personal & Ex: 58.4 & Ex: 52.2 \\
& Public & Ex: 58.5 & Ex: 54.7 \\
Angry & Personal & Ex: 36.9 & Ne: $\mathbf{4 0 . 2}$ \\
& Public & Ex: 35.2 & Ne: $\mathbf{3 5 . 4}$ \\
Sadness & Personal & Ex: 31.1 & Ne: $\mathbf{4 1 . 1}$ \\
& Public & Ne: 29.5 & Ne: $\mathbf{3 8 . 6}$ \\
Fear & Personal & Ex: 35.2 & Ne: $\mathbf{4 5 . 2}$ \\
& Public & Ex: 56.3 & Ex: 38.5 \\
Surprise & Personal & Ex: 58.4 & Ex: 38.7 \\
& Public & Ex: 53.4 & Ex: 43.1 \\
Disgust & Personal & Ex: 42.1 & Ne: $\mathbf{3 0 . 3}$ \\
& Public & Ex: 35.5 & Ne: $\mathbf{3 1 . 9}$ \\
Contempt & Personal & Ex: 31.6 & Ne: $\mathbf{4 5 . 2}$ \\
& Public & Ne: 29.9 & Ne: $\mathbf{3 9 . 5}$ \\
\hline
\end{tabular}

Note. $\mathrm{Ne}=$ Neutralization; $\mathrm{Ma}=$ Masking; $\mathrm{De}=$ Deamplification $\mathrm{Qu}=$ Qualification; Ex = Expression; Am = Amplification 
Table 5

The Display Rules of Emotion for the Target Persons 'Acquaintance' and 'Close-friends' for the Chinese and the non-Chinese Participants in Personal and Public Situations

\begin{tabular}{|c|c|c|c|c|c|}
\hline \multirow{4}{*}{ Emotion } & \multirow{4}{*}{ Situation } & \multicolumn{4}{|c|}{ The Target Persons } \\
\hline & & \multicolumn{4}{|c|}{ The Highest Display Rules (\%) } \\
\hline & & \multicolumn{2}{|c|}{ Acquaintance } & \multicolumn{2}{|c|}{ Close-Friends } \\
\hline & & (Chinese) & (Non-Chinese) & (Chinese) & (Non-Chinese) \\
\hline \multirow{2}{*}{ Happiness } & Personal & Ex: 45.9 & Ex: 41.3 & Ex: 61.5 & Ex: 54.5 \\
\hline & Public & Ex: 39 & Ex: 36 & Ex: 55.9 & Ex: 51.1 \\
\hline \multirow[t]{2}{*}{ Angry } & Personal & $\mathrm{Ne}: 38.2$ & $\mathrm{Ne}: 29.5$ & Ex: 26.2 & Ex: 29.2 \\
\hline & Public & $\mathrm{Ne}: 48.2$ & Ma: 32.2 & Ne: 33.9 & Ma: 28 \\
\hline \multirow[t]{2}{*}{ Sadness } & Personal & Ne: 44.9 & $\mathrm{Ne}: 49.2$ & Ex: 31.3 & Ne: 27.3 \\
\hline & Public & Ne: 51.3 & Ne: 52.7 & Ne: 35.1 & Ne: 33 \\
\hline \multirow[t]{2}{*}{ Fear } & Personal & $\mathrm{Ne}: 43.6$ & $\mathrm{Ne}: 34.1$ & Ex: 35.4 & Ex: 34.1 \\
\hline & Public & Ne: 51 & $\mathrm{Ne}: 47.3$ & Ne: 39 & $\mathrm{Ne}: 36.4$ \\
\hline \multirow[t]{2}{*}{ Surprise } & Personal & Ex: 39.7 & Ex: 27.7 & Ex: 56.4 & Ex: 48.9 \\
\hline & Public & Ne: 31.3 & $\mathrm{Ne}: 33.3$ & Ex: 42.3 & Ne: 39.4 \\
\hline \multirow[t]{2}{*}{ Disgust } & Personal & Ne: 33.8 & Ex: 29.5 & Ex: 42.2 & Ex: 37.9 \\
\hline & Public & Ne: 40 & $\mathrm{Ne}: 26.5$ & De: 35.5 & De: 24.5 \\
\hline \multirow[t]{2}{*}{ Contempt } & Personal & $\mathrm{Ne}: 41.8$ & $\mathrm{Ne}: 34.1$ & Ex: 32.1 & Ex: 24.2 \\
\hline & Public & $\mathrm{Ne}: 42.1$ & Ne: 42.4 & Ne: 39 & Ne: 39 \\
\hline
\end{tabular}

Note. $\mathrm{Ne}=$ Neutralization; $\mathrm{Ma}=$ Masking; $\mathrm{De}=$ Deamplification; $\mathrm{Qu}=\mathrm{Q} \mathrm{u}$

the summary of similarity and differences of display rules chosen by the two ethnic groups, to express the basic emotions toward target persons.

Target person: family. Table 4 shows that the Chinese were more likely to choose 'expression' in private places to express the seven emotion (happiness, anger, sadness, fear, surprise, disgust and contempt), toward the family members. They also chose 'expression' in public places to express emotion (happiness, anger, fear, surprise, disgust) to their family members. But they preferred neutralization to express sadness and contempt.

The non-Chinese were more likely to choose 'neutralization' to express emotion toward family members, either in private places (anger, sadness, fear, disgust and contempt) or in public places (anger, sadness, fear, disgust and contempt). They also chose 'expression' to show happiness and surprise in private and public places, toward family members. In public places, they also chose to use 'expression' to express their fear, toward family members.

Target persons: acquaintance. Table 5 shows that the Chinese were more likely to choose neutralization in private places to express emotion toward their acquaintances. They chose neutralization mainly to express anger, sadness, fear, suprise, disgust and contempt to acquaintances. They also chose 'expression' to express happiness and surprise to acquaintances in private places. They also chose neu- tralization to express anger, sadness, fear, disgust and contempt to acquaintances, in public places. To express happiness in public places, they chose 'expression.'

The non-Chinese were also more likely to choose neutralization to express anger, sadness, fear and contempt toward their acquaintances in private places. And they also chose 'expression' to express happiness, surprise and disgust. They also chose 'expression' to show happiness and masking to show anger, in public places.

Target persons: close friends. The Chinese were more likely to choose 'expression' to express the seven emotion (happiness, anger, sadness, fear, surprise, disgust and contempt) in private places toward their close friends. They also chose neutralization to express anger, sadness, fear, and deamplification to express disgust.

The non-Chinese participants also chose 'expression' to convey happiness, anger, fear, surprise, disgust and contempt, in private places, toward their close friends. To express sadness toward their close friends in private places, they chose neutralization. In public places, they chose 'expression' to show happiness and surprise toward their close friends. To disclose sadness, fear, suprise and contempt in public places, they chose neutralization. And they chose masking to show anger in public places.

Target person: school-mates. Table 6 shows that the Chinese were more likely to choose 'express- 
Table 6

The Display Rules of Emotion for the Target Persons 'School-mates' and 'Teachers' for the Chinese and the non-Chinese Participants in Personal and Public Situations

\begin{tabular}{|c|c|c|c|c|c|}
\hline \multirow{4}{*}{ Emotion } & \multirow{4}{*}{ Situation } & \multicolumn{4}{|c|}{ The Target Persons } \\
\hline & & \multicolumn{4}{|c|}{ The Highest Display Rules (\%) } \\
\hline & & \multicolumn{2}{|c|}{ School-Mates } & \multicolumn{2}{|c|}{ Teachers } \\
\hline & & (Chinese) & (Non-Chinese) & (Chinese) & (Non-Chinese) \\
\hline \multirow[t]{2}{*}{ Happiness } & Personal & Ex: 45 & Ex: 42.4 & Ex: 49.8 & Ex: 39.6 \\
\hline & Public & Ex: 41.2 & Ex: 35.6 & Ex: 34 & Ex: 29.9 \\
\hline \multirow[t]{2}{*}{ Angry } & Personal & Ex: 26.25 & Ex: 28.7 & Ne: 27.5 & Ma: 33.3 \\
\hline & Public & Ne: 37.4 & Ne: 31.6 & Ne: 41.2 & Ne: 40.3 \\
\hline \multirow[t]{2}{*}{ Sadness } & Personal & Ne: 42.6 & Ne: 40.4 & Ne: 37.3 & Ne: 44.7 \\
\hline & Public & Ne: 49.1 & Ne: 45.5 & Ne: 51.9 & Ne: 50.4 \\
\hline \multirow[t]{2}{*}{ Fear } & Personal & Ne: 42.6 & Ne: 42.4 & Ne: 36.4 & Ne: 39.8 \\
\hline & Public & Ne: 48.4 & Ne: 41.5 & Ne: 46.3 & Ne: 43.2 \\
\hline \multirow[t]{2}{*}{ Surprise } & Personal & Ex: 41.6 & Ex: 37.1 & De: 32.3 & Ex: 32.6 \\
\hline & Public & Ex: 35 & Ex: 27.7 & De: 29.5 & Ne: 35 \\
\hline \multirow[t]{2}{*}{ Disgust } & Personal & Ex: 33.9 & Ex: 30.8 & Ne: 44.2 & Ne: 36.2 \\
\hline & Public & Ne: 31.7 & Ne: 27.9 & Ne: 46.8 & Ne: 36.6 \\
\hline \multirow[t]{2}{*}{ Contempt } & Personal & Ex: 27.6 & Ex: 30.6 & Ne: 42.8 & Ne: 33.1 \\
\hline & Public & Ne: 35.6 & Ne: 32.1 & Ne: 48.1 & Ne: 37.1 \\
\hline
\end{tabular}

ion' in private places to express happiness, anger, suprise, disgust and contempt toward school mates. They picked neutralization mainly to express sadness and fear to school mates in private places. They also prefered 'expression' to disclose happiness and surprise to school mates in public places. Neutralization was picked to express anger, sadness, fear, disgust and contempt to schoolmates, in public places.

The non-Chinese participants showed very similar choices with the Chinese to express emotion toward school mates, either in private or in public places. To express happiness, anger, surprise, disgust and contempt in private places, they prefered 'expression'. They chose neutralization to show sadness and fear. To disclose happiness and surprises in public places, they chose 'expression'. And they prefered neutralization to express anger, sadness, fear, disgust and contempt.

Target person: teacher. Table 6 shows that the Chinese participants chose neutralization to express anger, sadness, fear, disgust and contempt in private places toward teachers. They prefered 'expression' to convey happiness in private places, and deamplification to represent surprise in private places. The Chinese participants showed the same dispositions in expressing emotion toward teachers both in private and in public places. They chose neutralization to express anger, sadness, fear, disgust and contempt; and 'expression' was their choice to show happiness; deamplification was picked to state surprise.
The non-Chinese participants selected neutralization to express sadness, fear, disgust and contempt in private places toward teachers. They selected masking to convey anger and 'expression' to state happiness and surprise. In public places the non-Chinese picked neutralization to state most their emotion toward teachers. It was only to convey happiness that the non-Chinese participants selected 'expression.'

\section{Results Summary of Emotional Expression Toward the Target Persons}

The following summary explains the display rules of emotion picked by the research participants to convey basic emotion toward target persons. This summary contained the sameness and the differences of rules picked by the Chinese and the nonChinese to state the seven basic emotion, in both private and public places, toward target persons.

Targeted person: family. The Chinese and the non-Chinese participants showed similarity in expressing happiness and surprise toward their family members in private places. Their expression of anger, sadness, fear, disgust and contempt were quite different.

The Chinese and the non-Chinese participants showed similarity in expressing happiness, surprise, fear, and contempt toward their family members in public places. But their expression of anger and 
disgust toward their family members was quite different.

Targeted person: acquaintances. The Chinese and the non-Chinese participants showed similarity in expressing their emotion toward acquaintances in private places. The differences were found only in their expression of disgust in private places.

The research participants were similar in expressing their emotion in public places toward their acquaintances. The differences between the two groups were found when they expressed anger in public places.

Targeted person: close friends. In private places, both Chinese and non-Chinese participants seemed to be similar in expressing emotion toward close friends. The differences between the two groups of participants were found in the diplay rule of sadness.

The two groups were also similar in expressing happiness, sadness, fear, disgust, and contempt toward close friends in public places. The differences between the two groups of participants were found in the display rule of anger and surprise.

Targeted person: school mates. There were no differences between the two groups in expressing emotion toward school mates, both in private and public places.

Targeted person: teachers. The groups were the same in expressing emotion toward teachers in private places. The similarities between the two groups of participants were found in the display rule of happiness, sadness, fear, disgust and contempt. The differences between them were found in the display rule of anger and surprise toward teachers in private places.

The differences between the Chinese and the nonChinese were found in the display rule of surprise toward teachers in public places. But they were similar in expressing other kinds of basic emotion.

\section{Discussion}

Based on the research result charts of the display rules of emotion and the target persons, the Chinese and the non-Chinese had several similarities and differences in emotional expression.

From the point of view proposed by Holodynski et al. (2006), the different emotional expression between the two groups of research participants were likely to happen since they had learned different emotional expression from their culture. According to the sociocultural context, the participants learned emotional expression from the adults around them, and these adults had the understanding of cultural meaning systems. The adults' responses to the participants when they expressed emotion as children, had been learned in such a way that they understood the meaningful interpretations of the responses. The participants later internalized the understanding and learned whether the emotion they expressed was suitable or not suitable to the cultural standard in the society where they were raised. These interpretations were learned and internalized and later integrated into their personality, and then applied during the adolescence. When they reach adulthood, these interpretations remain. The research findings showed that the Chinese and the non-Chinese in the Batam Island differ in conveying their emotion. These findings were in line with the argument pro-posed by Holodynski et al. (2006). Each group of participants had learned different things from their culture.

The theory stated by Holodynski et al. (2006) could also explain the similarities of these two different ethnic groups. The people of these two ethnicities had been living harmoniously in the island of Batam for years and their life had given the individuals the space to learn emotional responses and its meaning. Like children who learned from adults around them, so were the individuals in the groups, they learned from each other and internalized the emotional expressions suitable to the values they hold. The standardized values then accomodated the lessons learned, consequently the new standard values emerged. This emerging new values were then passed on to the next generations who participated in this research. This process explained the research findings that showed similarities and differences in emotional expression between the two groups. Futher explanations are needed to confirm these findings and to understand how they happen. Further studies are also strongly advised to compare these two groups of participants who live in the Batam Island with those who live in other places. Several big cities in Indonesia are suitable places to carry out further researches. In those cities the Chinese seem to mingle with people of other ethnicities more intensively than the ones in the Batam Island. The cities where the 17 non-Chinese participants come from can be a suitable alternative location for future research to be held.

The point of view stated by Holodynski et al. (2006) is helpful enough to understand the similarities and differences found between the Chinese and the non-Chinese of the Batam Island, when they con- 
vey emotion. As it was written in the beginning of this paper, Buana (2012) stated that there were misunderstandings during the social interaction between the Chinese and the non-Chinese in the Batam Island. The theory proposed by Holodynski et al. (2006) explained the misunderstandings. The theory explained in detail the reasons behind the facial expressions. The misunderstanding emerged in the very beginning when they socialize and this misunderstanding was actually coming from the differences in emotional expression they had learned from the family where they were raised. Similar arguments also explained the misunderstanding in the classroom where a non-Chinese teacher responded to the behavior of a Chinese pupil, as it was written by Buana (2012). The teacher and the pupil had learned different emotional expression from their families.

The insight of the similarities and the differences in emotional expression among the Chinese and the non-Chinese in the Batam Island was acquired through the argument proposed by Holodynski et al. (2006). This insight would be helpful to avoid misunderstandings that frequently happen in social interactions. The false impressions emerged from emotional expression interpretations that were unsuitable. This insight would also be useful for counselling or mentoring programs for conflict resolutions in which the conflicts usually caused by the mis-interpretation of others' emotional expression, especially of people of other ethnicities, in the Batam Island.

The empirical findings of the similarities and differences in intercultural emotional expression were generally supported by this research results. This study applied the point of view proposed by Holodynski et al (2006) on emotional expression. Matsumoto dan Ekman (1989) started the study of intercultural emotional expression. They rated the facial expression in the US and in Japan. Russell (1994) then reviewed the studies across different cultures. Araki dan Wiseman (1996) did the research on emotional expression from collectivistic and individualistic points of view; Fernández, Carrera, Sánchez, Páez, and Candia (2000) related the emotional expression with the verbal and non verbal reactions; Safdar, et al. (2009) did the study on emotional expression in Canada, in the US and in Japan; Grandey, Rafaeli, Ravid, Wirtz and Steiner (2010) specifically found the relationship between emotional expresion with cultural relationship, jobs and cultural expectation; Matsumoto, Willingham, and Olide, (2009), did the study on emotional expression among olympic athletes, and Yuki, Maddux and Masuda (2007) examined emotional cues in the facial expression. Other findings were reported by Beaupré and Hess (2005), Elfenbein and Ambady (2003), regarding emotion recognition, as well as Jack, Garrod, Yu, Caldara, and Schyns (2012) regarding its relationship with mental models, and Matsumoto (2006) about emotion regulation mediated by personality traits.

From the theoretical point of view, this review which was based on the argument proposed by Holodynski et al. (2006) was an alternate to the theory of social identity. According to Tajfel (as cited in McLeod (2008)), social identity is the sense owned by an individual about his/her identity, based on his/her membership in groups. According to Tajfel (1979), groups are important source of pride and one's selfesteem. Groups give a sense of social identity. Further, Tajfel and Turner (1979, as cited in McLeod, 2008), stated that social identity involved three mental processes in judging others, if he/she is ingroup, us, or he/she is out-group, them. The mental processes involved were consecutively social categorization, social identification and social comparison. The explanations about these processes in this study was as follows. Through social categorization, the Chinese participants in the Batam Island acknowledged themselves as belonging to the group of Chinese. Consequently they would think that their behavior were suitable to the norms in his/her group. The emotional expression - as part of human behavior - would be well-suited with the norms in Chinese group. Later on the Chinese participants would absorb Chinese identity through social identification process.

During the social comparison process, the Chinese participants were likely to compare his/her group (in-group) with other groups (out-group). The other groups were the groups of non-Chinese in the Batam Island. On the other hand, the non-Chinese in the island, through the social categorization, acknowledged themselves as belonging to their ethnic groups. They did not belong to the Chinese group. Consequently, they would think that their behavior was suitable to the norms of his/her original ethnic groups. As part of human behavior, emotional expression would be in line with the norms of the ethnic group where he/she belongs. The non-Chinese participants would later absorb his/her ethnic identity through social identification.

The non-Chinese participants were likely to compare his/her group (in-group) with other groups (outgroup) during the social comparison process. This mental process explained the emotional expression 
differences between the Chinese and the non-Chinese participants in the Batam island. All the participants acknowledged themselves to be members of different ethnic groups. Accordingly they need to show the appropriate behavior, not to mention the ways to convey emotions. All the participants later absorb their own group identities and eventually differentiate his/her group where he/she belong from other groups. This differences were considered as the cause of misunderstanding as stated by Buana (2012) in the beginning of this report. The similarities between the Chinese and the non-Chinese participants in expressing emotion could be seen from the point where they concurently identify their own selves and identify their selves to the bigger groups such as the group of Batam inhabitants. This bigger group was seen as their in-group which differentiate them from out-group.

\section{Limitations and Direction for Future Studies}

The Chinese participants in this study were chosen through two-stages cluster random sampling. . NonChinese participants were chosen with the same technique, but without considering equal proportions for each of the ethnic group. There were seventeen non-Chinese ethnics of the participants involved in this study (each ethnic group was represented by less than $10 \%$ participants). They were recruited through incidental sampling and consequently they were not proportional in number. As a result, to precisely describe emotional expression of the Chinese, compared to the ones of people of each ethnicities in the Batam Island, further study is needed. The study is advised to consider the proportion of each ethnics representations.

In light of the richness of Indonesia ethnicities, the findings of emotional expression studies should be complemented with the results of studies on emotional expression of each ethnic in Indonesia, in order to promote the uniqueness possibly found during the research.

The DRAI self-report developed by Matsumoto and Yoo (2007) was certainly not truly complete. Since all the data were taken from the participants, it is recommended that the self-report was combined with other measures, such as behavior observation technique. This is important for the comprehensiveness of the emotional expression studies.

Holodynski et al. (2006) explained that feeling, physiological reactions and expression all were in- volved in understanding emotion. The expression was the beginning of the process of understanding. Emotional expression was one of many possible expressions conveyed by human beings. The measurement of emotional expression offered by DRAI was developed by Matsumoto and Yoo (2007). This measurement was used as an assessement tool for emotional expression. In order to achieve deep and complete understanding of the emotional expression process, another assessment tool is required to measure the feeling and the physiological reactions. The feeling and physiological reaction measurement is important, for example, for individual counselling session which is highly personal.

The analysis of this study was based on the argument of Holodynski et al. (2006). The data obtained was only about emotional expression which was the 'results' of cultural to personal transformation process. In order to get a deeper understanding on emotional expression development process, the research data could have been completed with the data on family involvement in which the transformation process occured, both in the Chinese and the non-Chinese participants.

The analysis of this study was based on the argument of Holodynski et al. (2006) particularly the transformational process of cultural to personal emotional expression. The uniqueness of the transformation 'process' in the Chinese family could have been understood through the emotional expression measurement of the Chinese participants in the Batam Island (which is geographically small), which could then be compared with the Chinese in other islands, such as those who live in big cities in Indonesia. By doing so, it could be clearly explained if the possible assimilation differences in daily social interaction between the Chinese and the non-Chinese also affected the transformation process and the emotional expression.

\section{Conclusion}

Related to the emotional expression studies in Indonesia (Prawitasari, 2000), the findings of this research presented more specific data, from the Batam Island inhabitants. The research held by Prawitasari (2000) explained that there was an inclination to engage in masking among the participants, the negative emotion was changed into positive one. This study indicated that masking particularly used by the non-Chinese in the Batam Island, to convey their anger in public places. 
It is important to get the insight on differences and similarities of emotional expression among people of different ethnicities. It is also important to understand the cultural meaning system of each ethnicity. The different standard values held by each ethnicity could be integrated to form new standard values which could then be passed on to the next generations. This understanding is necessary for counselling or advocacy programs for conflict resolutions purposes in particular, since conflicts may rise from misunderstanding on others' emotional expression.

\section{References}

Araki, F., \& Wiseman, R. L. (1996). Emotional expressions in the United States and Japan. Intercultural Communication Studies, VI(2), 13-32.

Beaupré, M. G., \& Hess, U. (2005). Cross-Cultural emotion recognition among Canadian ethnic groups. Journal of Cross-Cultural Psychology, 36(3), 355-370.

Buana, Y. H. (2011). Ikhtisar wawancara mengenai budaya Etnis Tionghoa di pulau Batam (Unpublished manuscript). Fakultas Psikologi Universitas Padjadjaran, Jatinangor.

Buana, Y. H. (2012). Studi eksplorasi mengenai etnis Tionghoa di pulau Batam (Unpublished manuscript). Fakultas Psikologi Universitas Padjadjaran, Jatinangor.

Djunaidi, A., Setiono, K., \& Purwono, U. (2008). The display rules assessment inventory (DRAI) versi bahasa Indonesia (Unpublished manuscript).

Ekman, P. (1992). Are there basic emotions? Psychological Review, 99(3), 550-553. Available online at: http://www.paulekman.com/wp-content/uploads/ 2009/02/Are-There-Basic-Emotions1.pdf.

Ekman, P., \& Friesen, W. V. (1969). The repertoire of nonverbal behaviors: Categories, origins, usage, and coding. Semiotica, I, 49-98.

Elfenbein, H. A., \& Ambady, N. (2003). Universals and cultural differences in recognizing emotions. Current Directions in Psychological Science, 12(5), 159-164.

Fernández, I., Carrera, P., Sánchez, F., Páez, D., \& Candia, L. (2000). Differences between cultures in emotional verbal and non-verbal reactions. Psicothema, Suplemento, 12, 83-92.

Grandey, A., Rafaeli, A., Ravid, S., Wirtz, J., \& Steiner, D. D.(2010). Emotion display rules at work in the global service economy: The special case of the customer. Journal of Service Management, 21(3), 388-412. Available at www.emeraldinsight.com/ 1757-5818.htm.

Holodynski, M., Friedlmaier, W., \& Harrow, J. (2006). Development of emotions and emotion regulation. New York: Springer.

Jack, R. E., Garrod, O. G., Yu, H., Caldara, R., \& Schyns, P. G. (2012). Facial expressions of emotion are not culturally universal. Proceedings of the National Academy of Sciences, USA, 109(19), 7241-7244. doi:10.1073/pnas.1200155109

Matsumoto, D., \& Ekman, P. (1989). AmericanJapanese cultural differences in intensity ratings of facial expressions of emotion. Motivation and Emotion, 13(2), 143-157.

Matsumoto, D. (n.d.) Display Rule Assessment Inventory. San Francisco State University. Available online at http://www.davidmatsumoto.com/content/ AbridgedDRAI.pdf.

Matsumoto, D. (2006). Are cultural differences in emotion regulation mediated by personality traits? Journal of Cross-Cultural Psychology, 37(4), 421-437.

Matsumoto, D., Yoo, S. H., Hirayama, S., \& Petrova, G. (2005). Development and validation of a measure of display rule knowledge: The display rule assessment inventory. American Psychological Association.

Matsumoto, D., Yoo, S. H. (2007). Methodological considerations in the study of emotion across cultural. In J. A. Joan \& J. J. B. Allen (Eds.), The handbook of emotion elicitation and assessment (pp. 332-348). Oxford University Press. Available online at http://proquest.com

Matsumoto, D., Willingham, B., \& Olide, A. (2009). Sequential dynamics of culturally moderated facial expressions of emotion. Psychological Science, 20(10), 1269-1274. Downloaded from pss.sagepub.com at Yale University Library.

Mio, J. S., Hackett, L. B., \& Tumambing, J. (2009). Multicultural psychology: Understanding our diverse communities ( $2^{\text {nd }}$ ed.). New York: McGraw-Hill.

McLeod, S. (2008). Social identity theory. Available online at http://www.simplypsychology.org/socialidentity-theory.html

Prawitasari, J. E. (2000). Emosi dan ekspresinya dalam masyarakat. Available online at http://johana. staff.ugm.ac.id/wp-content/uploads/emosieekspresinya dalammasyarakat.pdf

Russell, J.A. (1994). Is there universal recognition of emotion from facial expressions? A review of the cross-cultural studies. Psychological Bulletin, 115(1), 102-141.

Safdar, S., Friedlmeier, W., Matsumoto. D., Yoo, S. H., Kwantes, C. T., Kakai. H., \& Shigemasu, E. (2009). Variations of emotional display rules with- 
in and across cultures: A comparison between Canada, USA, and Japan. Canadian Journal of Behavioural Science, 41(1), 1-10.

Setiady D. A. (2010). Pengaruh pemberian feedback negative terhadap perilaku menghindar: Studi mengenai prasangka terhadap etnis Tionghoa (Unpublished manuscript), Fakultas Psikologi Universitas Padjadjaran, Jatinangor.

Sindhunata, G. (2006). Teori Rene Girard: Kambing hitam. Jakarta: Gramedia.

Sutrisno, E. (2006). Tionghoa Batam: Dulu dan kini.
Batam: Batam Link.

Turner, S., \& Allen, P. (2007). Chinese Indonesians in a rapidly changing nation: Pressures of ethnicity and identity. Asia Pacific Viewpoint, 48(1), 112-127.

Yuki, M., Maddux, W. W. \& Masuda, T (2007). Are the windows to the soul the same in the East and West? Cultural differences in using the eyes and mouth as cues to recognize emotions in Japan and the United States. Journal of Experimental Social Psychology, 43, 303-311. Available online at www.sciencedirect.com 